\title{
INSTITUTE AFFAIRS
}

OFFICERS OF STANDING COMMITTEES

Forest Entomology \& Forest Pathology:

Chairman-R. R. Lejeune, Forest Insect Lab., Box 156, University of Manitoba, Winnipeg, Man.

Secretary - W. B. G. Denyer, Dom. Lab. of Forest Pathology, 309 Birks Bldg., Saskatoon, Sask.

Secretary for Entomology-Dr. Ken Graham, University of B.C., Vancouver, B.C.

Secretary for Pathology-J. T. Basham, Laboratory of Forest Pathology, 144 Front St. W., Toronto, Ont.

Forest Fire:

Chairman-J. C. MacLeod, Forestry Branch Department of Resources and Development, Ottawa, Ont.

Secretary -A. W. Braine, Chief of Forest Protection, Manitoba Forest Service, Winnipeg, Man.

Land Tenure and Taxation:

Chairman-J. Miles Gibson, University of New Brunswick, Fredericton, N.B.

Reforestation:

Chairman-Ed. Bonner, Woodlands Dept., Spruce Falls P\&P Co. L.td., Kapuskasing, Ont.

Secretary -A. H. Bamford, 201, 1162 Fort Street, Victoria, B.C.

Silviculture:

Chairman-Prof. George S. Allen, Facuity of Forestry, University of British Columbia.

Secretary - V. H. Phelps, 813 Dom. Public Bldg., Winnipeg, Man.

Soils and Site:

Chairman-G. Angus Hills, Box 242, Thornhill, Ont.

Surveys:

Secretary -N. Kissock, Marathon Paper Mills Ltd., Port Arthur, Ont.

Chairman-H. E. Seely, Forestry Branch, Department of Resources and Development, Ottawa, Ont.

Secretary -W. H. Hilborn, Fredericton, N.B., Univ. of N.B.

Wildlife:

Chairman-C. David Fowle, Division of Research, Ontario Dept. of Lands and Forests, Toronto, Ont.

Secretary-J. F. S. Bendell, Dept. of Biology, Queen's University.

Woodlot Management:

Chairman--J. L. Van Camp, Gen. Mgr. Can. For. Assoc., 4795 St. Catherine St., Montreal 6, P.Q.

Wood Utilization:

Secretary-M. R. Wilson, Extension Forester, Cdn. Intern. Paper Co., Montreal, Quebec.

Chairman-J. H. Jenkins, Chief of Forest Products Laboratories Division, Forestry Branch, Department of Resources and Development, Ottawa, Ont.

Secretary -C. R. Silversides, Abitibi Power \& Paper Co. Ltd., 408 University Ave., Toronto, Ont. 


\title{
NEWS OF THE SECTIONS
}

\author{
Quebec
}

Edgar Porter, Chairman of the Section, is scheduled to visit the Scandinavian Countries for three months to report on forests and forest industry for the Quebec Forest Industries Association.

I. F. Fogh, Vice-chairman of the Section, left for Europe last month on a forestry fact-finding journey.

Several Quebec C.I.F.'ers played prominent roles in the 35th Annual Meeting of the Woodlands Section, C.P.P.A., which was organized and directed by W. A. E. Pepler, Woodlands Section Manager and a past Chairman of the Quebec Section. B. W. Flieger was the recipient of the J. A. Bothwell Award, for meritorious service to Forest Conservation in Canada, at this meeting for his organization and direction of "Operation Budworm"- the 300square-mile spraying of budwormed forests in Northern New Brunswick. Francois Matte was also an award winner-his paper, "Silvicultural Requirements and Cutting Methods", resulted in his receiving the Price Brothers \& Co. Award.

The Tree Farm Movement in Canada, which is being co-ordinated by J. L. Van Camp's Canadian Forestry Association, is receiving active support and impetus from L. H. Paquet's Woodlands Section Private Land Forest Management Committee. The endeavour is to be launched officially during Forest Conservation Week, May 16-23. Several local committees have been organized already through the efforts of Messrs. Van Camp and Paquet with able assistance from M. R. Wilson, J. A. Breton and W. A. E. Pepler.

J. C. Boynton, Valcartier Forest Experiment Station, is the new Secretary of the Section, replacing Leif Holt.

Ted Cadenhead has resigned his position with Consolidated Paper Corp. to work in Finland on that country's National Forest Survey.

Contributed by E. T. OWENS

\section{SAGUENAY}

A regular meeting of the Saguenay Section was held at Chicoutimi on Saturday, May 30.

Mr. Stan Rutledge, resident engineer of the Chute des Georges development, addressed the meeting. His very full and interesting description of the development was enhanced by colored films, and the profiles and plans which he distributed to the audience and used in his talk.

The Chute des Georges development is an engineering undertaking which from the start has had considerable effect on the physical character of the forest operations in the vicinity, and will continue to influence local forest industries 
and management plans for years to come. As this hydro-electric project on the Shipshaw river is now nearing completion, Mr. Rutledge's contribution to the meeting was both timely and relevant, and he demonstrated that he combined ample technical knowledge with a lucid and unaffected delivery.

During the business session which preceded Mr. Rutledge's address, Mr. P. L. Morais, who occupied the chair, announced the names of the new executive which takes office on July 1st. The new office-holders, elected this spring in accordance with the by-laws, are the following:

$\begin{array}{ll}\text { Chairman: } & \text { M. Georges Vaillancourt } \\ \text { Vice-chairman: Mr. C. A. Charlton } \\ \text { Councillors: } & \text { Messrs. Roch Allaire } \\ & \text { T. Hassel } \\ & \text { J. R. Hughes } \\ & \text { Michel Corriveau } \\ & \text { P. Lucien Morais }\end{array}$

Mr. D. J. Vance continues faithfully in the office of Secretary-Treasurer.

The more important matters discussed during the balance of the meeting included the qualifications for membership other than active; the advisability of section dues being collected by the national authority, which would then reimburse the section; and the question of joint meetings with the local branch of the E.I.C. This last aroused considerable interest.

The day's activities were climaxed by a dinner for members and their ladies, at that really excellently appointed hostelry, the Manoir Clairval. Our thanks are due to Cecil Charlton who achieved a model of organization in his arrangements for the dinner, and our sympathy to those who were unable to attend a very enjoyable social affair.

\section{OtTawa Valley}

The 1952-53 season has been a most enjoyable and memorable one for the members of the Ottawa Valley Section; guest speakers have been exceptional and the variety of activities has led to excellent attendance.

First speaker of the season was J. D. B. Harrison of the Federal Forestry Branch. Mr. Harrison, in an entertaining talk on the Sixth British Commonwealth Forestry Conference held in Ottawa last summer, traced the history of previous conferences and indicated the extent of organization and planning that is necessary for such events. He also paid tribute to the late Lord Robinson for the role he played in making the 6th conference such a huge success. Host for that December evening was the E. B. Eddy Company which supplied a welcome pre-Christmas turkey dinner. 
Dr. Fay Bender of the Federal Forest Products Laboratories, gave "Some Impressions of a Visit to Yugoslavia" at the second meeting held in January. Dr. Bender discussed political and forestry conditions encountered during his tour of duty in that country, where he was assisting in the development of new wood-using industries as part of the $\mathrm{FAO}$ post-war reconstruction program.

For our third meeting, some seventy members converged on Cornwall, Ontario, in February, where we were guests of the Howard Smith Paper Mills Limited. Following a conducted tour of the pulp and paper mills, dinner and refreshments were provided by the company at the King George Hotel, Speakers for the evening were H. Mason, Mill Manager, and Dr. G. H. Tomlinson, Director of Research. Mr. Mason outlined the procedure for obtaining and processing the lumber through the mills, while Dr. Tomlinson delighted the guests with some notes on his tour of duty with FAO in Rome.

The wives and lady friends were the centre of attraction at the fourth meeting when a Dinner Dance was held in the Canadian Grill of the Chateau Laurier on March 7.

Bruce McColl, Mechanical Engineer in the Woodlands Section of the Canadian Pulp and Paper Association, Montreal, rendered a first-hand account of the recent "Trends and Developments in Mechanical Logging" at meeting number five held in April. Mr. McColl, with the aid of some interesting slides, outlined the mechanical steps involved in cutting timber and moving it to the mill. Refreshments were provided for the evening by the Lower Ottawa Forest Protective Association. A discussion, led by Peter Morley, on the subject of Professional Recognition for foresters in Ontario, was held during the business session.

At this writing members are preparing to attend the sixth and final meeting of the season for this section, and once again we are indebted to the E. B. Eddy Company for playing the part of host.

The following members are slated to hold office for the 1953-54 season: Alex Kingston, Chairman; Gil Cunningham, Vice-Chairman; Dave Gray, Section Representative on the Board of Directors of the parent body; Gerry Doyle, Ennie Steele, Jack Farrar, Bob Fraser, and George McGee council members; and Pat Rielly, Editorial Representative.

A note of interest to many in forestry is that a member of this section Allan O'Gorman, better known as "Al", has left the Federal Forestry Branch after nearly forty years with that service. "Al" was widely known in the surveying and mapping professions, in which he was an expert on forest and land mapping systems. At a gathering of the Staff on April 15, Dr. Macdonald paid tribute to the valuable services rendered by our "Al". 


\section{SOUTHERN ONTARIO}

Meetings of the section were held on January 14, February 11, March 11 and April 8, 1953.

The January meeting was held in Clarendon Hall, and dinner and refreshments were served to fifty members. The report of the professional recognition committee was presented and Mr. Yoerger, Solicitor of the Department of Lands and Forests spoke on the types of professional societies and the means of obtaining recognition. The draft bill is to be mimeographed and circulated to the members after which a vote will be taken by ballot.

Mr. D. V. Love of the Faculty of Foresrty gave a very instructive address in the field of economists in forest management. He recommended advances on the basis of taking the estimates of forest economists as to future requirements and using the knowledge of silviculture we already possess, which is sufficient to make a good start towards a sound forest policy.

At the February meeting Mr. Gordon Godwin, Manager of the Woodlands Department, Ontario Paper Company, gave one of the most interesting talks of the year on the teaching of Conservation principles in Ontario. The meeting was held in the music room at Hart House.

On March 11, the meeting was again held in the music room at Hart House. Thirty-five members were present.

The guest speaker of the evening was Mr. Gordon Goundrey, Economist with the Treasury Department of Ontario. He spoke on the economic atmosphere in which forests must be operated if sustained yield is to mean anything. He referred particularly to government policies which affect products and markets and to the presence of a large amount of overmature material in the forest which should be utilized. This situation could be handled by temporary expansion of the industry at home or by export of raw materials. Under such circumstances there did not seem to be any reason for banning the export of such material.

The chairman Mr. Walter Giles reported on the activities of the year.

Mr. A. S. L. Barnes, who attended the annual meeting as a section representative, reported to the section on the proceedings at the Montreal meeting of the Institute.

The activities of the Education Committee were covered in a report to the section particularly those activities that relate to the Conservation Workshop at Dorset. The Department of Education has announced the intention of continuing the Conservation Workshop this year and has appointed Mr. J. L. Van Camp as Principal. The scope and function of the Dorset teacher's course has been sent to the Lakehead Technical Institute and there is a possibility that another conservation course may be started at Port Arthur.

The term of reference of this committee has been revised and the name is now "The Committee on Education and Publicity"; its function is to 
promote better understanding among foresters, the public and the press, and to give improved counselling service to students and teachers.

The meeting on April 8 was held in Clarendon Hall. Forty-nine members were present and refreshments were served. The business meeting heard reports of the Section Representatives: The Education and Publicity Committees: The Woodlot Management Committee; the Programme Committee; the Professional Recognition Committee, the Nominating Committee. This committee proposed the following slate of officers:

Chairman, E. Gage; Vice Chairman, G. Sinclair; Councillors, R. Dixon, D. Hall, D. Hughes, and F. Leslie.

Mr. Clarke moved amendments to the by-laws to allow the appointment of separate treasurer and secretary for the section. This was carried.

The main business meeting was given over to a discussion of the proposed act for professional recognition of foresters. Mr. W. A. Delahey, Professor R. C. Hosie, Mr. R. Silversides, Mr. C. Longley, and Mr. T. E. Mackey spoke to the meeting with Mr. J. B. Mathews in the chair.

With one exception the speakers were either in favor of the proposed act or not opposed. One was not in favor of it on the grounds that foresters in the past had risen to the top without the aid of an act. Some speakers on the other hand said the failure to pass Bill 34 had set foresters back seventy years. No reason was given for the choice of this period of time. The principal feature that appeared to meet with favor by all was that the legally recognized body could speak with one voice for foresters whether in industry or government.

Contributed by A. P. LesLIE

\section{NORTHWESTERN ONTARIO}

To what might be termed a Lakehead Forestry Congress came foresters from Southern Ontario and from Algoma, Thunder Bay and Kenora districts, in mid-April. Although the meetings during the two day period were held under the auspices of three different organizations, they were concerned with professional matters of considerable importance and were attended, therefore, with keen interest by a large group representative of all agencies interested in or concerned with the management of Ontario forests.

Through the efforts of the Thunder Bay Timber Operators' Association and the cooperation of the Department of Lands and Forests, a first annual meeting on forest management was held on April 13th, in Port Arthur.

At this meeting, chaired by $\mathrm{H}$. $\mathrm{H}$. Styffe, papers on the subject were presented by Frank Sharpe, Chief of the Division of Timber Management Ontario Department of Lands and Forests, by R. Hummel, Management Forester for the Kenora District of the Department of Lands and Forests and by R. I. Young who presented the views of the wood-using industries in the district. While it was not expected that clarification of all aspects of current forest legislation would emerge from the discussion period which followed 
nor that positive definitions of mutually acceptable principles and objectives would be formulated-forest management, in all its ramifications does not easily lend itself to one day discussions-it was hoped, that there would be gained by industry and government representatives alike, a greater appreciation of the economic and technical problems which are being encountered and of the need for a more closely integrated attack in these problems. In this respect, the meeting was probably efficacious.

A meeting of representatives of district organizations and agencies interested in participation in co-operative regeneration surveys and studies, using the same or sinilar methods was sponsored by the North Western Ontario Committee on Co-Ordinated Research, on April 14th. This first open meeting was held to test the ability of the committee to achieve previously stated objectives, chief of which is to bring together agencies interested in given projects or problems and to eliminate thereby, unnecessary duplication of effort, while securing results which will be readily comparable through joint recognition of acceptable standards. The committee was particularly pleased to have in attendance Professor R. C. Hosie, of the Faculty of Forestry, University of 'Toronto, G. H. D. Bedell, of the Forestry Branch, Ottawa and A. R. McKenzie of the Abitibi Power and Paper Company, Limited, Sault Ste. Marie, all of whom contributed substantially to the success of the meeting through the experience they have acquired in the field of regeneration surveys. It was concluded that there was no apparent necessity for radical modification of sampling techniques currently used by the various organizatoins. Professor Hosie suggested that a real need, which had become apparent from his analysis of regeneration survey data, was for the provision of considerably more information with each report, indicating in detail the cover type symbols used, etc., and for the recording of additional data as to sites, previous stand ages, etc., during the course of the survey work. Further discussion was concerned with regeneration survey tally forms and with the desirability of improving these and possibly of designing a standardized form. The committee agreed to study forms currently in use and to undertake the design and circulation for comment and modification of a standard form which it is hoped will ensure the accurate and complete recording of all data required.

Over sixty foresters convened at the Prince Arthur Hotel in Port Arthur, on April 14th, for the annual meeting of the NorthWestern Ontario Section, Canadian Institute of Forestry. The section was pleased to have in attendance not only a large proportion of the regular membership, but also members of other sections, notably the Ottawa Valley, Southern Ontario, Central Ontario and Lake of the Woods Sections, who had attended the Forest Management and Coordinating Committee meetings, previously.

Acting Chairman K. W. Hearnden opened the business portion of the meeting for discussion of a number of important matters on the Section agenda and expressed Chairman Paul Ward's regrets that he was unable to preside at this final session of the 1952-1953 executive and members. 
Norman Kissick outlined his proposal for the formation of Chapters within the section as a means of more closely integrating the widely scattered groups of foresters in the district and of advancing the affairs of the Institute more effectively. Under Mr. Kissick's proposal, Chapter representatives would be appointed each year to the executive which would organize meetings from time to time within the Chapter area and would, whenever possible, attend important section meetings to express the views of the Chapter on important matters. It was suggested, also, that the Section annual meeting could well be expanded to fill a two day period, including discussions on professional issues, field trips, etc. It is expected that the 1953-1954 executive will implement this proposal in the near future.

The Chairman expressed the surprise and regrets of the section when confirmation of the formation of a new Lake of the Woods Section was given by a member in attendance. This development took place without the knowledge of the executive and without communication of any kind from any quarter. The congratulations and good wishes of the remainder of the section were extended, however, to this Western embryonic group.

Through 1953-1954, members agreed to contribute six articles on various aspects of forestry to the Thunder Bay Timber Operators' Association Log Book, as has been the practice for the past several years.

The principal topic for discussion on the business agenda was the proposed legislation and ballot in respect to professional recognition which was prepared through the efforts of the Southern Ontario Section.

Views were expressed on various aspects of the proposed legislation outlined in the memorandum forwarded to all foresters in the district, all of which seemed to indicate majority acceptance of whatever legislation may emerge.

As a result of the section annual election, the following executive officers were appointed for 1953-1954: Chairman, Mr. R. I. Young; Vice Chairman, Mr. O. Kantola; Secretary-Treasurer, Mr. N. Kissick; Editorial Representative, Mr. K. W. Hearnden; Counsellors, Mr. G. R. Sonley; Mr. C. J. Campbell; Mr. R. Boultbee.

"Bull-sessions" and the renewal of acquaintances were in order on adjournment of the business meeting until members reconvened for the dinner meeting.

The "Klondike Four" regaled the meeting with a number of songs and provided a contrast to the serious thoughts expressed by Professor R. C. Hosie, the guest speaker, on the subject of Professional Recognition for Foresters. His address provided an appropriate climax to the events and discussions during the two day meetings. 


\section{MANITOBA}

The Manitoba Section held what is generally hoped to be their annual dance at the Fort Garry Hotel on April 11. This is the second consecutive year for this affair, and judging from the post-mortem remarks, everybody that attended is looking forward to the next one in 1954.

Some recent changes have been made in the Federal Forestry Branch staff at Winnipeg. Bob Haig has come on as the new Liaison Officer for the Canada Forestry Act in Manitoba and Saskatchewan, thus lifting half the burden from Ed. Buckley who will henceforth work only in Alberta and British Columbia. Chuck Kirby has left the Forestry Branch and will be working out of Saskatoon as a surveyor. The position vacated by John Fingland last fall is to be filled by Jim Cayford who has been working for the province during the last winter. Stan Rowe was married May 1st in Haney, British Columbia, to Julie McQuoid.

The forest inventory program of the Manitoba Forest Service 1952-53 was completed satisfactorily. Most of the various phases of the work reached the original estimate and in some cases surpassed it. Forest mapping was greately accelerated and advance photo interpretation and base mapping is nearing completion for this coming summer's field work. The Surveys Branch, at the request of the Forest Service, completed 110 miles of the 20th. base line, west of the Principal Meridian, 121 miles of road traverse west of Island Lake and about 59 miles of lake shore traverse. These lines are used for control in connection with the slotted template base-mapping carried on by the Air Photo Library for the Forest Service. About 23,880 square miles of control base-mapping was completed this past fiscal year by the Air Photo Library.

A new nursery is now being built at Hadashville for Manitoba's expanding reforestation program. A new four-year agreement between the Dominion Government and the Province, under the Canada Forestry Act, promises over $21 / 2$ million trees within this period.

Poor moisture conditions are still prevalent in the South-eastern part of the Province, while fair to good conditions exist in the Western and Northern Sections. It is hoped that spring rains will relieve last fall's very low precipitation.

Contributed by R. R. LEJEUNE

\section{SASKATCHEWAN}

The Forest Pathology Laboratory, Saskatoon (Div. of Forest Biology, Science Service, Can. Dept. Agr.) provided the program of a meeting of the Saskatchewan Section, C.I.F., in Prince Albert on March 17. The program was in the form of informal discussions in which projection slides played an important part. 
Bruce Denyer discussed heart rots of spruce. With the aid of numerous samples he explained the classification of decays and the distinguishing characteristics of the several kinds encountered in Saskatchewan spruce. A report on this subject is being prepared for publication.

Roy Whitney and Herman van Groenewoud outlined an investigation of mortality in spruce stands characterized in advanced cases by openings in which all trees have died out during periods of several years. In this cooperative project ecological factors are being investigated by van Groenewoud, root infections by Whitney, and root attacking insects, (Hypomolyx), by $\mathrm{L}$. Warren of the Forest Insect Laboratory, Winnipeg. The results thus far obtained indicate that the primary factor probably is soil conditions which have been found to differ appreciably in the affected areas as compared with the surrounding "normal" stand. There appears to be a corresponding relationship as expressed by dead and infected roots. This investigation is being continued. Notes have been published in the Bi-monthly Progress Report, Div. of For. Biol., as follows: Warren and Whitney, July-Aug., 1951; Whitney, Jan. Feb., 1952; Whitney and van Groenewoud Nov.-Dec., 1952; van Groenewoud (submitted for publication) Mar.-Apr., 1953.

Olli Vaartaja gave an account of investigations of diseases of forest nurseries. Since he joined the staff last autumn, he has undertaken an ambitious program of research projects dealing with numerous infectious and physiological diseases of seedlings. A troublesome condition in seed beds at Indian Head is caused by weak parasites in association with too much shade. (Note submitted for Bi-Monthly Report, Div. of For. Biol. March-April, 1953). A "red patch" disease of spruce seedlings at Big River is associated with a snow mold. Septoria musiva and Cytospora chrysosperma are responsible for important losses of poplar cuttings at Indian Head. Several nutritional and other problems are being investigated.

Rainald Thomas outlined the purpose, methods, and organization of the Forest Disease Survey. The Saskatoon Laboratory is responsible for the Survey in Saskatchewan and Manitoba in cooperation with the Forest Zoology Laboratories at Winnipeg and Indian Head. The field work is now an additional responsibility of the Forest Biology Rangers who formerly were responsible primarily for work in the Forest Insect Survey. Courses of instruction are being given to these men and to forest conservation officers. Precise collection report forms, and other instructional and reference material have been prepared and are available on application. This year, emphasis is being placed on obtaining data on the occurrence and intensity of Fomes pini, Hypoxylon canker of poplar, dwarf mistletoes of jack pine and spruce, and stem and needle rusts of conifers. C. G. Riley was chairman for this meeting. Numerous interesting discussions arose from questions from the floor.

Subscriptions to the Bi-Monthly Report, Div. of For. Biol. are free on application.

Contributed by C. G. RILEY 


\section{Rocky MountaIN}

On Saturday evening, May 2nd, this section held its annual meeting at Red Deer, Alberta.

The following members were elected to office for the 1952-53 season: Chairman, V. J. Nordin; Vice Chairman, J. L. Janssen; Secretary-Treasurer, W. C. McGuffin; Section Representative, V. Heath; Editorial Representative, A. Blyth; Councillors, S. R. Hughes, A. Rytz, J. D. Champion, R. D. Loomis. Contributed by W. C. MCGUFFIN.

\section{VANCOUVER}

Three interesting and diversified dinner meetings have been held recently: in February Mark Gormely spoke on his impressions of New Zealand forestry. Mark was recently in New Zealand for C. D. Schultz Ltd., Consulting Forester. In March Don Roberts, Project Manager, Canadian Bechtel Ltd., spoke on the trans-mountain oil pipeline. At the annual meeting in April, Dean J. Miles Gibson, Faculty of Forestry, University of New Brunswick, spoke on the spruce budworm control project following a motion picture on the subject.

A two-day field meeting was held on May 1 and 2 at Green Timbers Forest Nursery, U.B.C. Experimental Forest, and Canadian Forest Products' Chehalis logging camp. It was a joint meeting with the Puget Sound Section of the S.A.F. The Program Committee was chaired by Stan Hepher.

The new slate of officers for the Section in 1953-54 is: Braham G. Griffth, Chairman and appointed as Director; Mark Gormely, Vice-president; Jack Creighton, past Chairman; Larry McMullen, Phil Northcott, Ian Cameron, Stan Hepher and Don Buckland, members of Council.

Contributed by D. C. BUCKLAND 